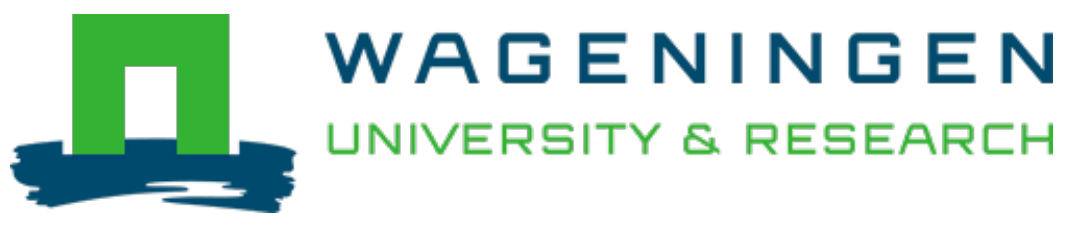

\title{
Rooted water collectives: Towards an analytical framework
}

Ecological Economics

Vos, Jeroen; Boelens, Rutgerd; Venot, Jean Philippe; Kuper, Marcel

https://doi.org/10.1016/j.ecolecon.2020.106651

This article is made publicly available in the institutional repository of Wageningen University and Research, under the terms of article $25 \mathrm{fa}$ of the Dutch Copyright Act, also known as the Amendment Taverne. This has been done with explicit consent by the author.

Article $25 \mathrm{fa}$ states that the author of a short scientific work funded either wholly or partially by Dutch public funds is entitled to make that work publicly available for no consideration following a reasonable period of time after the work was first published, provided that clear reference is made to the source of the first publication of the work.

This publication is distributed under The Association of Universities in the Netherlands (VSNU) 'Article $25 \mathrm{fa}$ implementation' project. In this project research outputs of researchers employed by Dutch Universities that comply with the legal requirements of Article $25 \mathrm{fa}$ of the Dutch Copyright Act are distributed online and free of cost or other barriers in institutional repositories. Research outputs are distributed six months after their first online publication in the original published version and with proper attribution to the source of the original publication.

You are permitted to download and use the publication for personal purposes. All rights remain with the author(s) and / or copyright owner(s) of this work. Any use of the publication or parts of it other than authorised under article $25 \mathrm{fa}$ of the Dutch Copyright act is prohibited. Wageningen University \& Research and the author(s) of this publication shall not be held responsible or liable for any damages resulting from your (re)use of this publication.

For questions regarding the public availability of this article please contact openscience.library@wur.nl 
Analysis

\title{
Rooted water collectives: Towards an analytical framework ${ }^{\text {hr }}$
}

\author{
Jeroen $\operatorname{Vos}^{\mathrm{a}, *}$, Rutgerd Boelens ${ }^{\mathrm{a}, \mathrm{b}}$, Jean-Philippe Venot ${ }^{\mathrm{c}, \mathrm{d}}$, Marcel Kuper ${ }^{\mathrm{e}}$ \\ ${ }^{a}$ Department of Environmental Sciences, Wageningen University, the Netherlands \\ ${ }^{\mathrm{b}}$ CEDLA Centre for Latin American Research and Documentation, University of Amsterdam, the Netherlands \\ ${ }^{\mathrm{c}}$ IRD, UMR G-EAU, University of Montpellier, France \\ ${ }^{\mathrm{d}}$ Royal University of Agriculture, Cambodia \\ ${ }^{\mathrm{e}}$ CIRAD, UMR G-EAU and University of Montpellier; IAV Hassan II, Rabat, Morocco
}

\section{A R T I C L E I N F O}

\section{Keywords:}

Rooted water collectives

Common-pool resources management

Social movements

Federations

Water governance

\begin{abstract}
A B S T R A C T
This paper presents an analytical framework to identify and understand grassroots water governance practices, which we call 'rooted water collectives' (RWC). RWCs can be multi-scalar organizations that engage in common property resources management or multi-scalar social movements that advocate for common property resources governance. The framework, which we open for discussion, scrutinizes (1) the extent to which 'rooted water collectives' are 'grounded' in the sense they address locally perceived water control problems and resort to water-context embedded meaning, values, identities, belonging and vernacular knowledge; (2) their internal decision-making dynamics; and (3) their effectiveness in achieving impact at multiple scales. It also considers five contextual factors that enable and constrain RWC development. RWC can be deployed as a conceptual lens, but also as an empirical manifestation constituting the object and subject of research. It differs from wide-spread top-down-implemented participatory water management approaches and common property resources management research, in the importance it gives to politics, advocacy and multi-scale social movements. The framework is illustrated with a cursory analysis of four cases: irrigators' federations in Peru; the 'new water culture' movement in Spain; collective irrigation in oases in North Africa; and loosely structured networks of irrigation water users in Cambodia.
\end{abstract}

\section{Introduction}

This paper sets out to present an analytical framework to identify and understand innovative grassroots water governance practices, which we call 'rooted water collectives' (RWC). Rooted water collectives are instances of collective action, coordination and shared governance arrangements that either engage in communal management of water systems (and may have second or more tier federations) or form a social movement that advocates for local common property resources management. Some rooted water collectives do both.

We contend that 'rooted water collectives' constitute an alternative framing to understand collective action dynamics around water management, which have largely been framed 'apolitically' around the notions of participatory management or common-pool resources (CPR) management. The notion of rooted water collectives can be used as a conceptual lens and as an object and subject of 'engaged research' to further our understanding of social mobilization in relation to water management. In the latter sense, rooted water collectives are actors and manifestations of grounded water governance with whom researchers can proactively engage in efforts of empowerment and democratization.

The proposed framework, which is open for discussion, identifies and scrutinizes practices related to these context-grounded forms of water control and governance arrangements. We contend that the concept allows to analyze in what ways these organizations build on local knowledges, site-developed, dynamic water cultures and collective decision-making, while interacting with the state and market institutions (Lankford and Hepworth, 2010; Komakech and Van der Zaag, 2013; Boelens et al., 2015). It also allows investigating how these water collectives experiment with innovative water governance principles, and how they develop institutional tools that empower local organizations through multi-scalar federations advocating for and defending collective resources management (e.g., Roth et al., 2005, 2015; Orlove and Caton, 2010; Johnston et al., 2012; Fuente-Carrasco et al., 2019).

Other conceptual frameworks such as the Institutional Analysis and Development framework (IAD) and the Social-Ecological System framework (SES) (e.g., Ostrom, 2009; McGinnis, 2011) have been

\footnotetext{
This article belongs to the VSI on "Social Movements and Commons", guest edited by S. Villamayor-Tomas, G. Garcia-Lopez and G. D'Alisa.

* Corresponding author.

E-mail address: jeroen.vos@wur.nl (J. Vos).
} 


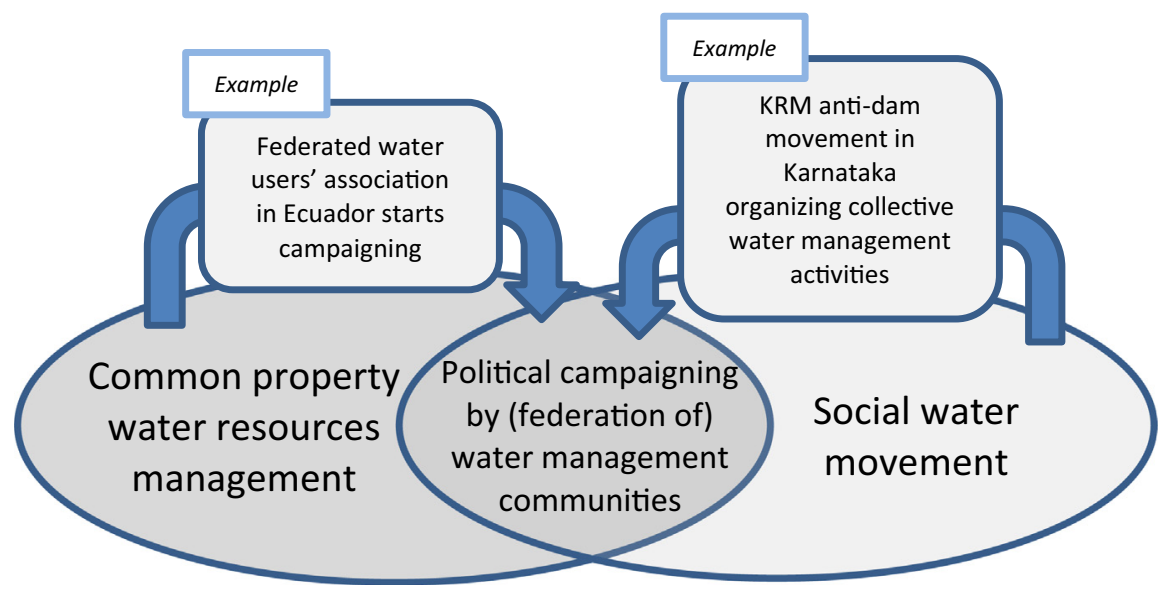

Fig. 1. Relation between local water commons and social water movements (own elaboration).

proposed to analyze common resources management and collective action and can yield insights on the above dynamics. The perspective we propose, however, significantly differs from those earlier frameworks by the importance it gives to issues of democratization, empowerment, justice and advocacy, rather than rational choice theory and new institutionalism. Further, the framework we propose abstains from, and critically challenges, commonly applied notions such as 'key organizational design principles', which may obscure rootedness, creative practices and people's contextual culture and contingency based water governance solutions. Our point here is not to dismiss the IAD framework (some of us have actually used it in their previous research), but to propose a different analytical lens that better allows to understand and support social mobilization in relation to common property management.

Scientific research has shown that communal organizations can be very successful in the protection of catchment areas, managing urban water, developing rural drinking water and irrigation systems, and devising strategies for climate change adaptation and coping with drought and flooding. Collective water governance in small and medium sized irrigation systems played an important role in highly diverse contexts that range from countries as Spain, Switzerland, Nepal, India and Tanzania to regions as North Africa, the Andean Highlands, the Middle East, and South-East Asia (e.g., Ostrom, 1990; Boelens and Vos, 2014; Mutambara et al., 2016; Woodhouse et al., 2016; Sillitoe, 2017). Lansing (1987) documented the impressing collective irrigation management by water collectives and priests in his seminal study on the Subaks of Bali. This also shows in the thousands of rural communities that manage their own drinking water systems and micro-watersheds in many parts of the world (e.g., Isham and Kähkönen, 2002). Flood protection in the Netherlands is another example of a long history of collective governance arrangements (Mostert, 2017). These studies have however mostly focused on the local organizations that manage the water resource, without regarding their translocal networks and their engagement with political advocacy practices.

However, there are critical water scholars who have documented examples of multi-scalar rooted water collectives around the world (e.g., Mosse, 2003; Dupuits and Pflieger, 2017; Suhardiman et al., 2017; Villamayor-Tomas and García-López, 2018). Examples of federations of collective irrigation organizations are the federations of water users' organizations in Chimborazo, Tungurahua and Cotopaxi provinces in Ecuador, which claimed and gained the right to inspect the work of the regional water authorities (Boelens et al., 2015; Hoogesteger et al., 2016). Other examples of federations of irrigators were described, among others, for Bolivia (Perreault, 2008), Nepal (Clement et al., 2017), Tanzania (Komakech and Van der Zaag, 2013), and Spain (Villamayor-Tomas, 2018). Departmental and national federations were documented for Ecuador and Colombia that bring together drinking water collectives, contesting also new governmental proposals to hand over system management to commercially driven private companies (Dupuits and Bernal, 2015). Federations of communal drinking water committees were also documented for Costa Rica (Gumeta-Gómez et al., 2016), Nicaragua (Romano, 2017) and Nepal (Clement et al., 2017).

Other types of rooted water collectives do not manage water resources directly, but engage in advocacy and defense of water users collectives and citizens' involvement in water governance. An example are the grassroots-federated water courts (regional water tribunals) in Latin America that, though overlooked by formal powers, have strong legitimacy and defend environmental rights (Global Water Forum, 2014). Another type of rooted water collective is the Foro de Recursos Hídricos (Water Forum) in Ecuador that organizes debates and research on water management across the country, and mobilizes that knowledge and activities into a social movement that has been able to effectively claim for grassroots-oriented legislation (Hoogesteger, 2016; Goodwin, 2019). This form of rooted water collective is similar to the New Water Culture movement in Spain and Portugal that will be described below. Instead of single-dimension organizations these organizations present pluriform dynamics that emerge as concrete answers to local issues on water governance, but at the same time have much wider social impact (De Castro et al., 2016).

From these examples it becomes clear that rooted water collectives can be either multi-scalar organizations that engage in communal management of common property resources or multi-scalar organizations that form a social movement, alliance or federation that advocates for democratic common property resources governance (see also Villamayor-Tomas and García-López, 2018). Some rooted water collectives may not have a strong multi-scalar structure. Fig. 1 shows the overlap that can exist between, on the one hand, 'common property water resources management' and, on the other hand, 'social water movements'. In the overlapping sphere we find rooted water collectives that both manage common property resources and engage in advocacy activities.

Three examples are given of organizations that combine direct resource management with being social movements. The water users organizations federated in some Ecuadorian provinces, introduced above, manage irrigation or drinking water systems individually, while collectively going up the scalar ladder to engage in (inter-sector) struggles for defending water rights and lobbying to improve water policies. In the case of the proposed privatization of the Thessaloniki drinking water company in Greece, in 2011, the K136 social movement proposed the users would buy the company (at a share of $€ 136$ per person, thus the name of the movement) to establish a common management of the drinking water system (Van den Berge et al., 2018). In this case, this plan of 'going down the scalar ladder' was not realized, 
showing the difficulty of advocacy and social mobilization networks to materially "root in" water collectives. Ideas of social water movements that did materialize are, for example, the ways in which the Kengrehalla Rejuvenation Movement (KRM) in Karnataka, India (which started as an anti-dam movement) organized on-the-ground collective water management activities (SOPPECOM, 2010). Dupuits et al. (2020, in this Volume) show the opportunities (e.g., growing voice and outreach) and pitfalls (e.g. standardization or 'distantiation') of water commons going 'up and down the ladder' (see also, Richard Ferroudji, forthcoming).

Rooted water collectives differ from other collectives that manage natural resources like forests, mining sites, fishing grounds, or grazing lands due to the fugitive nature of water: it is difficult to store and leaks away easily. Water management is specific as it often demands much labor input (in operating, maintenance and repair of infrastructure) and involves socio-technically mediated access to hydraulic artifacts meaning power plays can easily result in exclusion of access for some. Nevertheless, given the parallels with other resource management collectives and the set of interconnected and generic markers we propose, the framework may also be of interest to other communities of scholars, practitioners, resource users or policy-makers.

The need for introducing 'rooted water collectives' as both a conceptual lens and a diverse, empirical reality, stems from the observation that, conceptually, existing frameworks such as IAD/SES fall short of highlighting the political dimension of common property resources governance and the social movements that underpin them. Empirically and politically, the RWCs are crucially important for real-life water control. Their entwined empirical-productive and political-institutional importance is often overlooked in studies on CPRM.

Rooted water collectives are not merely traditional and local, but dynamically combine principles and rules from diverse normative sources (local, national and global rules) and hybridizes indigenous, colonial, and contemporary norms (von Benda-Beckmann et al., 1998; Boelens, 2015; Roth et al., 2015). As such, their empirical manifestations present their own inequities and internal injustices; they do not represent a 'utopia', but rather evolve from dynamic and complex interactions among different stakeholders with different values, interests, and knowledge backgrounds (Schulz et al., 2017). As all management and governance collectives, they do not guarantee positive outcomes for all beforehand but are the vibrant arena of power plays, 'governmentalities' and counter-strategies (Foucault, 1991; Chatterjee, 2004; Li, 2007).

A further characteristic is that rooted water collectives often remain below the radar of conventional water law and environmental policymaking or, worse, are actively sidelined or incorporated (e.g., Gelles, 2000; De Vos et al., 2006; Boelens, 2015; Woodhouse et al., 2016). This happens because rooted water collectives often challenge official water policies in order to build alternative water governance forms and 'grounded' water solutions. But meanwhile, they also strategically engage with state regulations and market conditions - even though the strategies they employ are often misrecognized or not known.

Studying RWCs thereby allows to see that water governance institutions are mostly not developed and cannot be implemented in a linear top down way (with some 'participation of stakeholders'), but instead are the outcome of struggles, social learning, networking, and negotiation by multiple actors (Long, 2004; Lankford and Hepworth, 2010; Hoogesteger and Verzijl, 2015; Kuper et al., 2017). The notion goes beyond a simple bottom-up vs. top down dichotomy. Many forms of 'co-production' may develop: not just 'State-community' but also 'community-private sector' institutional assemblages, and sometimes even multi-stakeholder platforms (see Warner, 2006) that were set up for deliberation and negotiation but not for managing or defending water may transform into RWCs - this way crafting new political subjects, relations and institutions that may strengthen or weaken water user collectives' autonomies (Goodwin, 2019).

We examine local and supra-local forms of water collectives as a continuum; these grassroots entities strategically make use of both dominant and non-dominant knowledge, rules and norms repertoires thereby hybridizing and entwining them (von Benda-Beckmann et al., 1998; Roth et al., 2005, 2015; Sanchis-Ibor et al., 2017). Rooted water collectives are multi-scalar arrangements and practices that struggle not only over the water resources, infrastructures, water policies and projects, but also over the discourses that legitimize, render comprehensible and give meaning to water reality.

Most current day water policies overlook RWCs, and instead try to create participation of water users in a top down way. Consequently, participation of water users or affected people in water development projects is often reduced to using their labor, or to the mere informing or consulting of a limited number of people, and envisioned along the prism of their economic contribution to system maintenance. In that way water users' associations are implemented as single organizations around one purpose (e.g., managing an irrigation system), positioned in a hierarchical relation to an irrigation department or ministry at national state level (Molle et al., 2009). For example, in Colombia, participation in hydropower dam planning led to capture of the discourse by the pro-dam lobby (Duarte-Abadía et al., 2015) while in Cambodia (Ivars and Venot, 2019) and Thailand (Ricks, 2015; Singto et al., 2018) (among many other countries) participatory irrigation management policy is mainly participatory on paper.

Real decision-making power is seldom transferred to the affected people and participatory policies are often ineffective and create obstacles for bottom-up water governance (Roth et al., 2005; Venot and Clement, 2013; Vos and Boelens, 2014). This may lead to either accommodation or acceptance of dominant ideas (Hommes et al., 2016; Cleaver, 2018; Swyngedouw and Boelens, 2018), to the irrigation bureaucracy and farmers making informal (and unsanctioned) adjustments (Lees, 1986), or to forms of open conflicts or 'rhizomatic' resistance (Deleuze and Guattari, 1987; Horowitz, 2011; Boelens, 2014; Hall et al., 2015).

The astute reader would have realized that the examples we give above draws a particular geography with countries where civil society organizations are particularly dynamic (e.g., particular regions of Latin America, South Asia, and Europe). One of our ambitions in this paper is to use a theoretical framework based on ideas that may have emerged in particular geographies to shed light on grounded water dynamics that play out in other contexts - hence contributing to a broader discussion on linking social movement and water resources management. We will analyze cases of water governance arrangements in Latin America, Southern Europe, North Africa and South East Asia, and discuss the extent to which these can be seen as rooted water collectives, paying specific attention to the contextual factors that enabled and constrain their development, and their internal structuring and functioning, as well as their strategies to engage with market forces, state organizations and diverse stakeholders at multiple scale levels.

\section{Theoretical background and analytical framework}

Our conceptual framework partially draws on, but also significantly diverges from different bodies of literature such as (1) common pool resources governance (e.g. Ostrom, 1990, 2009; Cox et al., 2010; Poteete et al., 2010) that largely focuses on understanding the determinants of local institutional arrangements for natural resources management; (2) 'new environmental governance' that stresses the mutual collaboration of stakeholders, deliberative decision-making, accountability and social learning (e.g. Holley et al., 2011); or (3) 'collaborative water management' approaches (e.g. De Boer et al., 2016) that focus on integrated participatory watershed and river basin management (for critiques, see e.g., Molle, 2008; Ananda and Proctor, 2013; Roth et al., 2015).

Two related frameworks for analyzing collective resource management are the Institutional Analysis and Development (IAD) framework and the Social-Ecological System (SES) framework, which expanded the 
idea of the Design Principles for CRP management (McGinnis, 2011). The IAD framework (Ostrom and Cox, 2010; McGinnis, 2011) scrutinizes the biophysical conditions, attributes of communities and their rules-in-use, and how they interact in so-called action situations. The SES framework expands the IAD framework to incorporate resource systems, governance systems, resource units and actors in focal action situations (Ostrom, 2009; Ostrom and Cox, 2010; McGinnis and Ostrom, 2014). The analytical framework we propose differs in major ways from the IAD/SES framework in five main points:

1. The ontology is different: RWC starts from people's struggles and the empowering and justice effects of collective action. It studies the dialectic relation between the material and the discursive, the collective and the state, and consensus-seeking and conflict (Hommes and Boelens, 2017; Villamayor-Tomas and García-López, 2018), where most IAD/SES scholars use a new-institutionalist / rational choice approach, engaging methodological individualism, to look at practices of CPR management. Our approach has more affinity with later "critical IAD" conceptualization (and therefore, is closer to critical realism approaches, as deployed by Clement (2009) and Whaley (2018)).

2. IAD/SES models the resource system and resource units, while the RWC focuses on socio-political interactions, including social movements that do not directly manage a resource.

3. RWC looks at federating of local RWCs for political advocacy, where IAD/SES tends to look at (supposedly) apolitical nested organizations as optimal organizational structure for CPR management (authors as Clement (2009); Epstein et al. (2014), Whaley (2018) and Brisbois et al. (2019) seek to expand the IAD/SES bringing 'power' into its focus).

4. RWC explicitly looks at state bureaucracy, strength of civil society and political room of maneuver (civil and press freedoms) as important enabling contextual factors.

5. RWC looks at the plurality of ontological understandings, epistemological perspectives, worldviews and values, including the disputes among discourses and multiple languages of valuation (Fraser, 2000; Martinez-Alier, 2002; Schlosberg, 2004; Duarte-Abadía and Boelens, 2016).

In terms of socio-political perspective, the RWC academic background and approach is constructivist and engaged with the questions and constraints of those who lack voice and economic/political power in water affairs, therefore explicitly focusing on key issues of social justice, power and politics, and (the contestation of) plurality. Consequently, when adopting the analytical framework, researchers and activists may often thereby interweave notions of vernacular water governance and practices with those of environmental justice (e.g., Roth et al., 2005; Zwarteveen and Boelens, 2014; Hoogesteger et al., 2016), deploy notions of governmentality (Foucault, 1991; Li, 2007; Boelens et al., 2015; Hommes et al., 2016) and seek to scrutinize how social norms and/or gender, class, caste or ethnic contradictions and relationships are embedded in water use artifacts, governance instruments and hydrosocial designs (e.g., Pfaffenberger, 1988; Meehan, 2013; Sanchis-Ibor et al., 2017).

Based on the study of a large number of case studies, the scrutiny of water governance, commons, and human and political ecology literature, and several decades of water governance field research in most of the world's continents by the authors, we have identified patterns and markers we consider most relevant for water-control grassroots' organizational functioning and effectiveness. The evolving analytical framework looks at 'rooted water collectives' scrutinizing three different dimensions (Fig. 2): (1) their rootedness, that is, the extent to which they are 'grounded' and aim at addressing issues while attaching to place-connected notions of identity, awareness, motivation and belonging; solidarity; social-ecological integrity; and use of vernacular water knowledge; (2) their internal structural dynamics of decision- making and capacities, which includes internal democratic practices (including gender equity); leadership and managerial capacities; negotiation capacities; knowledge and information sharing; and multi-tier organizational structure expressed as 'federated strength'; and (3) their effectiveness in achieving impact at multiple scale-levels, in terms of multi-scalar alliance building with other organizations; innovativeness, creativity and functionality; legitimacy and recognition of advocacy work; and redistribution and socio-environmental improvements.

Next, our frame of analysis considers how these dimensions are embedded in and influenced by broader economic, political and environmental dynamics, while they also partly contribute to shaping these structuring forces. The broader contextual factors relate to (see Fig. 2): (1) the strength and involvement of the state bureaucracy that can enable or restrain collective management, (2) the strength of civil society and room for maneuver, including civil rights and press freedom, (3) the functioning of agricultural markets and the economic environment of the water sector (e.g. a market for water rights or private company investments in irrigation infrastructure), (4) the academic and epistemological environment, indicating which environmental discourses, water ontologies and water-cultural worldviews are deployed, dominant, subjugated or made invisible in national and regional water governance debates and proposals, and (5) the technophysical and agro-ecological environment.

Just as dominant hydro-territorial projects, policies and designs, rooted water collectives' 'responses' are actively constructed, necessarily entwined, and historically produced through the power-laden interfaces between society, technology and nature. Therefore, the three dimensions reflect both 'internal' constitutional and operational processes and the embeddedness in and interaction with societal structures and processes at large (the five contextual factors). Together and interactively these shape the multi-dimensional characterization of, and critical support to, rooted water collectives.

\section{The case illustrations}

Four cases illustrations are presented to illustrate the large variation in functioning, scope and federated strength of organizations that manage common pool water resources and/or advocate for CPRM. We question the extent to which these instances fit with our definition of rooted water collectives. The cases from Peru, Spain, North Africa and Cambodia, by no means exhaustive or representative, pertain to four continents and widely varying contextual factors. The case study descriptions give different levels of importance to the elements of the framework, reflecting their importance for the case. Case study descriptions are based on literature research and complemented with interviews.

\subsection{National Federation of Water Users' Organization in Peru}

Agriculture in the arid coastal zone of Peru is sustained by a dozen large-scale irrigation systems, ranging from 10 to 120 thousand hectares. Most of them have a history going back more than ten centuries. The Spanish conquistadores established large landholdings (haciendas) that took over system management since the 16th century. The land reform of 1969 expropriated the haciendas and established State-directed farmers' cooperatives to manage the irrigation systems. A decade later, the cooperatives met with increasing internal management problems and were dissolved in the early 1980s, distributing the land among the former members. This resulted in many smallholders with on average some five hectares of irrigated land. System management by the Ministry of Agriculture regional offices became increasingly deficient: the distribution of water was erratic because of ill-motivated operators, and lacking maintenance of canals and distributing gates.

Between 1989 and 1998, the management of these large-scale coastal irrigation systems was turned over to water users' associations (Comisiones de Regantes) that became responsible for the operation and 


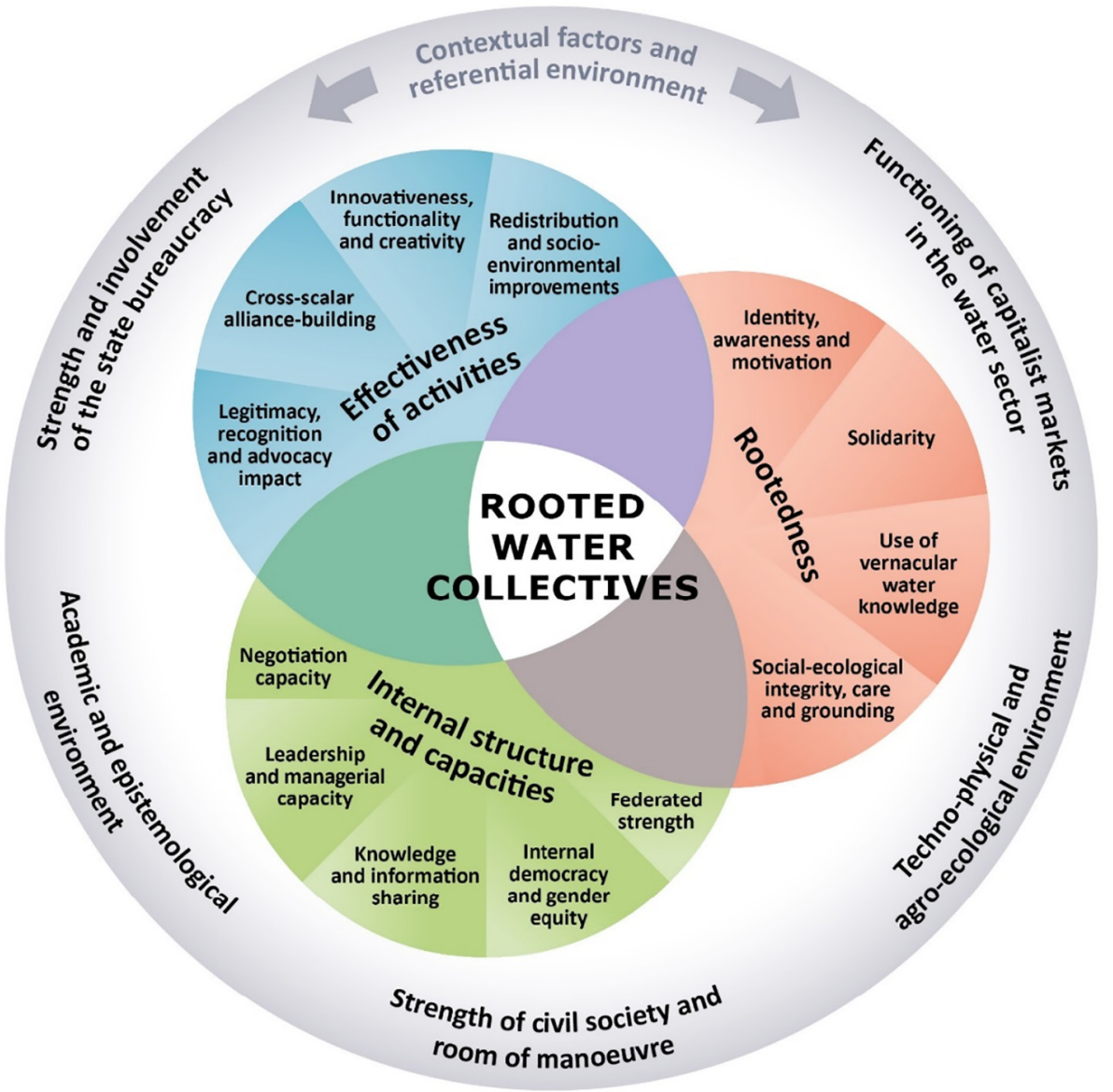

Fig. 2. The three dimensions of rooted water collectives (own elaboration).

maintenance $(\mathrm{O} \& \mathrm{M})$ of the secondary canals and water distribution to the individual farmers in the tertiary blocks. All Comisiones de Regantes together in one irrigation system formed a main system board (Junta de Usuarios) that could establish a company to operate and maintain the main irrigation infrastructure. The Comisiones de Regantes also established and collected the irrigation service fee to finance O\&M. The management board of each Comisión de Regantes was to be elected each two years from among all water users of each secondary canal. Notwithstanding the difficulties with internal management capacities and interference of national politics in the management, they managed the irrigation systems fairly well. At least, much better than the Ministry of Agriculture. This was due to: (1) the high levels of accountability of the elected board to the users; (2) the collaboratively established budget and fees for O\&M; (3) the high level of knowledge of the users and hired operators about their irrigation systems; and (4) the financial rewards for board members (Vos, 2005; Vos and Vincent, 2011).

As the Comisiones de Regantes and Junta de Usuarios were effective in running the irrigation systems and collecting the set water fees, they gained political importance. They had large financial turnovers and became the representatives of the over 300,000 farmers in the coast. The user boards became a springboard for wannabe politicians, and the boards negotiated important issues like agricultural subsidies and the new water law with the Ministry of Agriculture.

With the rising political importance of the system-scale Junta de Usuarios, their overarching association, the National Water Users' Organization (JNUDRP, Junta Nacional de Usuarios de los Distritos de Riego de Peru) became an important actor at the national political level. The JNUDRP was established in 1983 and represents all 117 Juntas de Usuarios in the Coast, Andean Mountains and Amazon Basin, which group together some 2 million registered water users. The JNUDRP gained importance as a body representative of the coastal farmers from the 1990s, when traditional small farmers' organizations and unions lost political weight. The JNUDRP was important in the many debates and protests leading up to the new water law of 2009, effectively lobbying and protesting against the privatization of water and the irrigation systems (see Oré et al., 2009; Oré and Rap, 2009). Their internal structure of organization favors the dominance of the representatives of the large irrigation systems in the North Coast. The board has only men (which reflects gender biases in general and in particular in water governance). Different from the irrigation system organizations, the federated JNUDRP management capacities are generally low, which can be observed in the variation in intensity of activities of the JNUDRP over the years.

With the increasing political importance of the JNUDRP also the internal struggle intensified. The Juntas de Usuarios from the Northern Coast, already the most powerful, demanded more say (vis-à-vis the Juntas of the Central and Southern Coast) as they represented the largest irrigation systems with the largest number of water users. In 2008, they established their own organization as an internal political move to increase their political weight within the JNUDRP.

However, the representatives of the thousands of small irrigation systems in the Andean highlands also fought to get their voices heard within the national political arena, through the JNUDRP. This was not successful, and in 2006, they tried to establish a separate association of irrigators from the highlands (Comisión Coordinadora de las Juntas de Usuarios de Agua de Sierra y Selva, CCJUSS) as they felt the JNUDRP only represented the interests of the Coastal irrigation systems. However, despite help from international development cooperation, CCJUSS never succeeded in organizing the thousands of small highland 
irrigation systems (Oré et al., 2009; Oré and Rap, 2009).

In conclusion, the JNUDRP is 'rooted' in the sense that they represent the medium-sized farmers on the Peruvian Coast. They do not identify with the image of the 'peasant', and do not voice the concerns of the indigenous peasant water users in the Andean region. They are against mining and illegal groundwater use, as this might affect the farmers in the coastal irrigation systems, but as a coastal farmer lobby they do not engage with wider visions on social-ecological integrity. The political agenda of the JNUDRP is dominated by lobbying for assistance from the government for infrastructure and subsidies for the smallholder and medium-sized irrigators in the Coast, and against the privatization of water and irrigation systems. JNUDRP has used successfully the threat of protests including road blockage by farmers to put pressure on governments to gain assistance for these smallholders.

\subsection{The 'New Water Culture' movement in Spain}

During the past century, Spain has seen a massive building of large water storage dams. During the dictatorship of General Francisco Franco many mega-dams were built, and local protests repressed (Swyngedouw, 2007). Part of Franco's national, all-encompassing 'Hydraulic Policy' was the water transfer of the Tagus River in the center of Spain to the south of the country to supply water for export agriculture. This mega hydraulic work was realized and put into operation in 1979 after the restoration of democracy in Spain. Researchers from the north of Spain started to investigate the risks of large dams built as part of these hydraulic works. In 1995, they established a platform (COAGRET $)^{1}$ to exchange experiences and document, together with activists, cases of negative effects of dams constructed in Spain (Gómez-Fuentes, 2012). Simultaneously, several of the members of COAGRET started to study and criticize the National Hydrological Plan (NHP), presented by the government in 1993, which included the building of ten new megadams and the water transfer from the Ebro river in the north to the Segura river in the south.

The debate on the NHP prompted the creation of an organization that was broader than COAGRET, and would include many different types of organizations, not only in Spain but also in Portugal, to discuss a wide variety of themes related to water governance: the value and aesthetics of water, water quality, ecological flows, recreational use of water, river basin management, and 'water culture'. This organization was called the New Water Culture Foundation ${ }^{2}$ (acronym FNCA, Fundación Nueva Cultura del Agua) (Gómez-Fuentes, 2012). FNCA is composed by over 200 academics from Iberian universities, environmental organizations and individuals. It publishes research reports, organizes the bi-annual 'Iberian Congress on Water Management and Planning', and is involved in a master program. ${ }^{3}$ Through years of engagement with local and regional environmental groups FNCA built a vast network of like-minded groups and individuals. In 2000 and 2002 large protest marches were organized in Zaragoza, Madrid, Barcelona and Brussels to oppose the Ebro water transfer. This contributed to abolishing the transfer project in the new NHP in 2005 (Broekman, 2013).

FNCA is engaged in several international water governance networks and covers many thematic fields, from climate change impact to mapping local water related conflicts. Members of FNCA engage in many local struggles for the defense of rivers and aquifers. The case of the local protest movement led by Acuiferos Vivos near Almeria is a

\footnotetext{
${ }^{1}$ At present, COAGRET has 27 institutional members that are environmental NGOs and local environmental organizations. It also has numerous individual members that might be academics, activists or interested individuals. See: http://www.coagret.com.

${ }^{2}$ See: https://fnca.eu/en/

${ }^{3}$ The master program at the University of Zaragoza is called "Máster Propio en Gestión Sostenible del Agua", see: https://www.universia.es/estudios/ universidad-zaragoza/master-propio-gestion-sostenible-agua/st/258815
}

telling example where inhabitants fight the depletion of the aquifer by newly established irrigated olive plantations. FNCA does not have a hierarchical management structure as it functions as a platform that hosts events, manifestations and research projects. Throughout the years, FNCA has grown into a strong and important water and environmental movement in Spain and Portugal that engages with many local initiatives and protests at local and regional level. At the same time, FNCA also has its institutional weaknesses. Bukowski (2017) noticed a diminishing influence of FNCA on national water policies since 2008 and more internal divisions: e.g. between the Spanish and Portuguese members, between the scientists and activists, and between engineers and members who give particular importance to the aesthetics of water (Bukowski, 2017). A closer analysis of different local water management and water-related conflict cases reveals different forms of synergies and differences between the local and national water movement.

An example is the protest against a dam planned in the Rio Grande near Malaga in the south of Spain. As explained by Duarte-Abadía et al. (2019), local farmers and villagers started opposition against the flooding of their land by the water storage reservoir and the diversion of the water they used for irrigation, drinking water, fishing and other livelihood-uses to the city of Malaga. The suspicion that the project was meant to benefit construction companies and luxurious tourist resorts also fueled resistance. A local organization of environmentalists and researchers (Asociación Cultural Medioambiental Jara) helped the farmer communities (organized in the Cerro Blanco Anti-dam Platform) and formed the Coordinating Body to Defend the Río Grande in 2006. The Coordinating Body did research and provided information on the project. Some Asociación Jara fellows were also members of FNCA. The ideas of the FNCA against large dams coincided with the interests of the local farmers to stop the dam-building project through a creative, multi-actor and multi-scalar water movement. However, after initial collaborative successes and halting the dam project, some environmentalist factions also critically looked at the (informal, customary) irrigation practices of the local farmer communities: they found the traditional weirs in the river an obstruction for fish migration routes and the traditional irrigation methods to be wasteful and therefore supported modernization proposals. But these irrigation modernization and 'technification' projects, presumably to 'save water', met with very diverging responses, both inside the farmer communities and from some environmentalist factions. Opponents feared the loss of ancient irrigation culture, agribusiness enterprise takeover, and the transfer of 'saved water' out of the valley to Malaga's tourist resorts. Competing worldviews and interests regarding water's cultural heritage, modernization and efficiency, environmental conservation and livelihood strategies, mark the difficulties to collectively withstand the new threats to the valley (DuarteAbadía et al., 2019).

In conclusion, FNCA is rooted in the sense that they are a multi-tier grassroots organization with many local and regional organizations, and based on local knowledge and identity, striving for social-ecological integrity. Contextual factors that influence the achievements of the water movement are the dominant discourses on economic development and efficient and modern irrigation systems that limit advocacy of the FNCA in Spain, at the one hand, and on the other, Spain's democratic system simultaneously allowed for FNCA's multi-actor and multi-scale responses against the further damming and domesticating of its rivers. As FNCA attention and action importantly concentrates on environmental issues in river basin governance, working together with the many irrigators' communities and their federations, who have long standing traditions of successful community irrigation water management, is not always part of their focus. This may imply that they miss opportunities to collaborate with peasant irrigators' commoning efforts, who struggle for re-collectivization of 'modernized' and privatized irrigation management - as happens in the East and South of Spain (Sanchis-Ibor et al., 2017). 


\subsection{Oasis water management in North of Africa}

In North Africa, the oases host some of the region's most ingenious community-managed irrigation systems, as local populations had to cope with very scarce water resources that were difficult to access. Some emblematic examples of such irrigation systems include the foggara (called khettara in Morocco, qanat in Iran), which are underground galleries leading groundwater by gravity to irrigated plots, the spate irrigation systems that divert and spread flash floods over land and the ghout, which are shallow basins allowing palm trees to draw water from nearby phreatic aquifers (Bisson, 2003). These community-managed irrigation systems are often admired for their elaborate irrigation infrastructure and contributions to landscape configuration, and equally for how they have shaped fine-tuned irrigation institutions, enabling access and governing the sharing of water (Hamamouche et al., 2017). At the same time, these strongly rooted customary institutions (dealing with issues including water rights and landownership) were based on strong social hierarchies and inequalities, and can in no way be described "as benign or as egalitarian" (Ilahiane, 2004; p. 89).

Agricultural development programs in the Sahara from the second half of the 20th century onwards have focused on developing marketoriented agriculture, based on the access to pumped groundwater, outside of the oases in the so-called 'extensions', thereby indirectly marginalizing existing oases. Often subsidized by the state and managed by individuals or small collectives, the access to groundwater enabled the rapid expansion of irrigated area of commercial date palm groves (medjool in Morocco, deglet nour in Algeria and Tunisia), greenhouse or field horticulture (tomatoes, potatoes, melons, water melons etc.), fodder crops and cereals. For instance, in the Biskra district in Algeria the irrigated area was multiplied by five, increasing from 16,615 ha in 1969 to 83,350 ha in 2008 (Kuper et al., 2016). Similarly, in the Nefzawa area in Tunisia, the irrigated area increased from 7000 ha in the 1970s to more than 16,000 ha in 2008 (Mekki et al., 2013). At a larger scale, the palm groves in the Algerian Sahara expanded from 5.5 million palm trees in 1959 to 12 million in 2000, and to 17 million in 2011 (see Kuper et al., 2016). In a context of socioeconomic change, massive urbanization (from $24 \%$ in 1966 to $68 \%$ in 1998 (Côte, 2005)) and social emancipation, these extensions endangered the collective irrigation schemes inside the oases (see Hamamouche et al., 2018). This was sometimes due to destructive water-related interactions (decline in water tables due to excessive pumping or rising water tables of the phreatic aquifer due to receiving the excess pumped water from deep aquifers), but was also linked to the departure of the former sharecroppers towards these extensions (or to other economic sectors), seen as less coercive and more profitable environments (Bisson, 2003).

Nevertheless, quite a number of the community-managed irrigation systems are still active today and a few are even re-activated, sometimes by those who had earlier left for the extensions. In these irrigation systems, the irrigators made a number of changes in the physical infrastructure (in some cases subsidized by the state) as well as in the institutions governing the access to and sharing of water (Hamamouche et al., 2017). For instance, Idda et al. (2017) report on five foggara reinforced by pumped groundwater in Adrar (Algeria); these were financed by the state after a social mobilization, as their foggara were running dry because of the drilling of a deep borehole in the vicinity for drinking water. Such dynamics illustrate the structuring of a RWC, which, as mentioned before, strategically engaged with the state to gain access to subsidies and technical support. Following this mobilization, not only the physical infrastructure of the irrigation system was changed (introducing a state-financed borehole to supply water to the foggara), but the irrigation institutions were overhauled as well: former sharecroppers, who had been instrumental during the social mobilization and had no water rights before the borehole was introduced, now received water rights and took management responsibilities in the irrigation community.
Yet, the rooted water collectives face a number of new, multi-scalar water-related challenges and many traditional oases continue to decline or are urbanized. For example, Côte (2005) showed that, in the early 2000s, 915 out of 9700 ghout in the municipality of Oued Souf (Algeria) had become waterlogged and 100,000 palm trees had died from asphyxiation, while many other ghout were threatened due to a rise in water tables of the phreatic aquifer caused by excess drainage water and urban waste water, originally pumped from the confined aquifer for drinking purposes. Whereas in the previous example an RWC structured itself and was able to negotiate with the state, this was not possible in this case due to the strength of the state bureaucracy and the absence of multi-tier RWC, constituting two constraining contextual factors. Examining oasis water management cases, through the lens of RWC, thus shows the need for social mobilization beyond the local scale, as broader, supra-local water-related interactions threaten multiple communities. At this moment, there are only a few examples of second- or third-tier rooted water collectives mobilizing around the need to protect the water resources on which community-based irrigation systems depend; for example, the international network of local associations for the safeguard of oases (RADDO: Associative Network for Sustainable Development of the Oases), created in 2001. This network supports local associations and encourages their involvement in developing public policies specific to oases.

\subsection{Farmer Water Net (FWN): a nascent 'water collective' in Cambodia}

In the 1990s, Cambodia, as many countries in the world, witnessed participatory irrigation management (PIM) reforms that were meant to improve the long-term sustainability of the many irrigation schemes that dot the low lying floodplains of the country. As part of these reforms, and alongside infrastructure rehabilitation, Water User Associations (locally called FWUC: Farmer Water User Community) were established with support from multiple donors (FAO, the Asian Development Bank, the French Agency for Development, JICA, etc.). Often established quickly, in a bureaucratic way, to conform to a decree that defined their responsibilities but also their organizational structure (mimicking an idealized irrigation infrastructure network), a vast majority of FWUC face well known problems such as a lack of legitimacy, low level of accountability, subjection to the administration, political interference from local elected bodies, and low O\&M capacity (see Ivars and Venot, 2019). At the same time the Ministry of Water Resources and Meteorology (MoWRAM) seems little interested in maintaining rehabilitated infrastructures and favors the construction of new schemes, in an attempt to gain support in rural areas in a political context that is increasingly disputed (see Blake, 2019).

The above dynamics are rather well known by water scholars worldwide (see for instance, Suhardiman et al., 2014). They stress the limits of participatory reforms in a country that has long witnessed the imposition of modes of government from outside and where civil society organizations are highly politicized (Formoso and Stock, 2016). It is then no surprise that participatory irrigation reforms have fallen short of democratizing water management. Yet there are instances of multi-level coordination around water management, which can be analyzed through the RWC analytical framework.

One of the reasons why FWUC have difficulties fulfilling their bureaucratically-defined role (e.g. recovering a water fee from farmers to be used for maintaining infrastructure) relates to the low profitability of rice production. Faced with such difficulties, and on their own initiative, some of the most active FWUC have decided to form paddy selling groups (those are sub-groups of people belonging to the FWUC) to be able to negotiate higher prices with traders and millers, hence answering one of the main concerns of their members. FWUC also engage in networking activities that have an international dimension, though these are largely driven by NGOs and international actors.

Since the 1990s, Cambodia has indeed seen the emergence of a multitude of international and local NGOs (Cambodia is the country 
with the highest number of NGOs per capita; Formoso and Stock, 2016). Though these NGOs face many challenges to operate in the current Cambodian political climate, they managed to position themselves (often with the support of international counterparts) as potential interlocutors of citizens and the administration. In the irrigation sector, the Irrigation Service Center (ISC) is such an organization. It has been set up in the mid-2000s with the support of the French cooperation and, since then, provides long term and context-specific support to recently established FWUC, using tools that aim at building FWUC capacity and ownership of infrastructure rather than telling them what they ought to do. ISC also acts as the secretariat of the Farmer Water Net (FWN). The FWN is a federation of 36 FWUC registered in 2011 in the Ministry of Interior; it serves as an experience sharing platform among FWUC but also gives them some level of (political) visibility vis-à-vis the Ministry (as can be the case for production-based farmer collectives -agricultural cooperatives). Such 'loose' networking strategy echoes other instances of civil society coordination existing in Cambodia; it allows citizen to exchange about issues they deem important while largely avoiding political control (see Formoso and Stock, 2016 for a similar argument). The capacity of the ISC and the FWN still need further strengthening and their existence and activities largely hinges on donor-funded projects, but they may announce a civil-society based water-commoning in a country where the main political party exerts strong political control over citizens and the administration alike.

In a country where the administration is closely linked to a highly personalized political system, patronage networks and family alliances constitute a pillar of social life (Formoso and Stock, 2016) and "civil society" has been built "from outside" by international development organizations, there are instances of coordination that may well herald the emergence of 'water collectives'. In the Cambodian case, RWC is mostly an analytical framework that sheds light on these water collectives rather than a term that can be used to characterize them. The multi-layered collectives we describe above are rooted (first dimension of the framework) in the sense that they try to address the main concern of their members (e.g. rice profitability) rather than their bureaucratically defined responsibilities for which they lack capacity (second dimension of the framework). Most interestingly, they are engaged in multi-layered networks (third dimension of the framework) to navigate a complex political space; leaving to internationally supported NGOs (the ISC) and loose network (the FWN) the task to negotiate with (rather than oppose) the administration, progressively questioning the balance of responsibilities.

\section{Discussion}

This section discusses the rooted water collectives framework. It especially highlights the connections between the three dimensions. In relation to the first dimension of our framework (rootedness), we asked the question as to how rooted water collectives face, produce or fight the context-specific interactions between water governance and socioenvironmental justice, and mobilize different types of knowledge to do so. In addition to Fraser (2000) and Schlosberg's (2004) three-fold notion of social justice (recognition, representation, distribution), the framework encourages to scrutinize if and how local water collectives materialize 'socio-ecological justice' and seek to sustain livelihood security for contemporary and future generations. The interplay between vernacular/grounded knowledge and environmental justice and care plays out differently in the case we described above - and strongly relate to issue of representation and recognition that we further discuss below. For instance, the local collectives for the management of water in oases in North Africa are making use of vernacular knowledge and have developed centuries-long understanding of their environment, yet this is coupled with very strong social hierarchies and inequalities. In Cambodia, vernacular knowledge is not really mobilized by water collectives (though it is by individual farmers as to when they decide to plant notably) and though strongly embedded in an economic rationality, payment to access water is adjusted depending on environmental conditions, reflecting a certain concern for social-environmental justice. The case from Spain on the other hand shows how water collectives, when they are able to hybridize different types of knowing and navigate different justification frameworks (supportive of e.g., environmental concerns or commoning of water management), can influence policy making. The framework stresses that decision-making authority, often determined by economic power relations and cultural and behavioral norms, is closely interlinked with how particular forms of water knowledge are legitimized and privileged.

In relation to the second dimension of our framework (internal structure and capacity of the water collectives), studies on common pool resources management often assume that 'capacity' comes together with some sort of democratic decision-making process. Ostrom (1990:90) presumed that for good working commons: "most individuals affected by the operational rules can participate in modifying the operational rules". But rather than focusing solely on the form of decision making (often simply equated to whether a collective organizes elections or not), practices of solidarity, respecting of minorities and protecting marginalized groups need to be accounted for as they are significant components of democratic practices. The notions of representation and recognition (of whose values and interests?) are fundamentally important when scrutinizing water collectives' governance practices. In that instance, the cases we describe above display well known representation challenges: gender bias, over representation of most welloff members, reinforcement of existing or creation of new patron-client relationships.

Yet, in most instances the water collectives we documented served as effective platforms for exchange of information and - to a lesser or more degree - in multi-scalar negotiation and advocacy through the creation and management of federations. Some collectives also display unequal power relations and representation of different groups. Interestingly, bias in representation and recognition seems to be reinforced as water collectives acquire a certain visibility and legitimacy vis-à-vis the state apparatus (the JNUDRP in Peru clearly displays this while it does not constitute a key feature of the weaker FWN in Cambodia). Therefore, rather than assuming the existence of rooted water democracy this is a matter of profound, empirical, case-by-case scrutiny.

The third dimension of our framework links the question of effectiveness to the ability of water collectives to engage in cross-scale advocacy and, through it, influence policy for socio-environmental improvement. The idea of justice is, again, central. Social movements like the New Water Culture in Spain and the Water Forum in Ecuador (see Hoogesteger, 2016; Goodwin, 2019) set examples of how alliances of academics, civil society groups and rooted water collectives can emerge and be effective in changing government policies. However, the two examples of articulation with local movements also show the difficulties in linking local concerns with general ideas promoted by the national federative organization. The members of FNCA are rooted in different ways in different places in Spain and Portugal. According to their focus and geographical position, they show differences in backgrounds, interests and ideologies. Forming a national platform founded on shared basic principles is an important challenge and may contradict particular locally held ideas and felt needs. While at local levels the FNCA is successful in engaging with water protection and river defense struggles, in particular cases their ideas may be perceived as 'external' and contradict with local views and felt needs.

In Ecuador the Water Forum has had much success at the national level, but also showed difficulties in articulating with different groups in Ecuador that have different interests. For instance, class-based ('peasant') claims for redistribution do not always neatly coincide with culture-based (e.g., 'indigenous') claims for recognition of vernacular water rules, rights, organizational forms and epistemologies; they may support each other, but also show conflicting interests (Hoogesteger, 2016; Goodwin, 2019). Upscaling 'local diversities' may strengthen but 
also requires translation and commensuration of particular demands possibly resulting in misrecognition or new exclusions (see also Dupuits et al., 2020, in this volume). These difficulties are worth bearing in mind as there seems to be an increased interest to address wider policy issues related to water and agricultural development in the cases of the North African oasis and the irrigation systems of Cambodia, due to the decline of some oases in connection to groundwater use (and disposal) in the recent agricultural extensions and sprawling urban centers in North Africa and due to concerns over long term sustainability of investment in Cambodia. In all cases, the tension between water movements and water management collectives, federated for mutual interests, requires continuous, critical and inclusive debates 'going up and down the ladder'.

\section{Conclusion}

Based on the above presented framework and four case illustrations we can draw some preliminary conclusions. Rooted water collectives are highly diverse and heterogeneous. The four cases also illustrate the importance of the circumstances under which water collectives function and develop. The five factors of contextual and referential environment (i.e., the broader dynamics and co-structuring forces, see Fig. 2) enable and constrain rooted water collectives; they tend to deeply shape and influence their governance organization and functioning. For instance, the limited political freedom for collectives in Cambodia restrains their development. The strength of the state bureaucracy in North Africa, associated with the absence of multi-tier rooted water collectives made it impossible to avoid the "drowning" of the ancient ghout systems. In Spain the multi-actor and multi-scalar water movement could develop after the restoration of democracy. In Ecuador, the strong civil society organizational tradition importantly contributed to the emergence of multi-scale federative grassroots initiatives and the national multi-actor water platform, challenging the state's top-down water governance institutes, policies and intervention practices.

Internally, decision making on resources allocation and management can take different forms: from hierarchical to democratic to clientpatron relations. Internal power differences may often be institutionalized along gender, class, ethnicity, age, and or land- and water holding divides. Finally, questions of rooted water control are intimately linked to, and interconnect, issues of participation, recognition, distribution and socio-ecological integrity, and ask for scrutiny as mutually reinforcing complexes.

Federations of rooted water collectives are important for advocacy and policy influencing of multi-scalar water-related challenges, and multi-actor and multi-scale exchange of experiences and knowledge, but run the risk of either being captured by the state, or only representing a specific interest group. Social movements advocating for increased attention to local water management obstacles and solutions, and the social and material claims of water collectives, may fail to address the on-the-ground issues that are important for rooted water collectives. In particular, they will need to consciously and continuously 'go up and down the ladder' and discuss and mediate the pitfalls of commensurating grassroots' claims and interests when they generalize the latter beyond local contexts and diversities.

Understanding rooted water collectives calls for a contextual, grounded, relational approach. It asks to move beyond universalist frameworks and theories or legal and institutionalist prescriptions that focus on what informal water commons or formal water users organizations 'should be.' The framework starts by understanding how people on-the-ground experience and define water control, institutions, rights, laws, technologies and territorial or multi-scale relationships - not taking them for granted but as starting points of analysis (cf. Zwarteveen and Boelens, 2014). Further, the framework distinguishes and simultaneously entwines distributive justice (the question of socioeconomic allocation), political justice (the issue of representation), cultural justice (dealing with recognition of diverse normative frames), and socio-ecological justice (the question of inter-generational sustainability). However, as the diversity of practices is enormous, the framework is not meant to compare rooted water collectives but rather to exhibit their existence and functioning, and scrutinize their effectiveness in defending and promoting just water management and influence policies. The cases from Peru and Spain show a high level of effectiveness to this respect. Attention for the emergence and functioning of rooted water collectives in Cambodia and the oases in Northern Africa reveals new insights on their dynamic development and interaction with government policies. Cross-regional and cross-cultural comparison may reveal important opportunities for mutual learning or even grassroots' cross-border engagement and solidarity, without falling in the trap of mainstream policies and neoliberal discourses promoting 'good governance' and 'best practices' - or policy-makers applying Elinor Ostrom's 'design principles' and adaptive management ideas to 'optimize' the water commons and make them 'resilient'.

Finally, even though the framework is set up to examine and critically support water governance collectives, the identified dimensions, patterns and markers of grassroots' organizational functioning, and the questions of how these are embedded in, influenced by, and simultaneously co-shape broader societal dynamics and structuring forces, may also be of interest to researchers, practitioners, and social leaders working on the governance of other natural resources.

\section{Declaration of competing interest}

The authors declare that they have no known competing financial interests or personal relationships that could have appeared to influence the work reported in this paper.

\section{Acknowledgement}

The authors would like to thank the Editors of the VSI on Social Movements and Commons: S. Villamayor-Tomas, G. Garcia-Lopez and G. D'Alisa, who also organized the IASC Workshop "Social Mobilization and the Commons: A Virtuous Circle?" in Barcelona, June 2018. We also acknowledge the supportive comments of two anonymous reviewers.

\section{References}

Ananda, J., Proctor, W., 2013. Collaborative approaches to water management and planning: an institutional perspective. Ecol. Econ. 86, 97-106.

von Benda-Beckmann, F., von Benda-Beckmann, K., Spiertz, J., 1998. Equity and legal pluralism: taking customary law into account in natural resource policies. In: Boelens, R., Dávila, G. (Eds.), Searching for Equity. Van Gorcum, Assen, pp. 57-69.

Bisson, J., 2003. Mythes et réalités d'un désert convoité: le Sahara. Editions L'Harmattan, Paris.

Blake, D.J.H., 2019. Recalling hydraulic despotism: Hun Sen's Cambodia and the return of strict authoritarianism. Austrian Journal of South-East Asian Studies 12 (1), 69-89.

Boelens, R., 2014. Cultural politics and the hydrosocial cycle: water, power and identity in the Andean highlands. Geoforum 57, 234-247.

Boelens, R., 2015. Water, power and identity. In: The Cultural Politics of Water in the Andes. Routledge, London, Washington DC.

Boelens, R., Vos, J., 2014. Legal pluralism, hydraulic property creation and sustainability: the materialized nature of water rights in user-managed systems. Curr. Opin. Environ. Sustain. 11, 55-62.

Boelens, R., Hoogesteger, J., Baud, M., 2015. Water reform governmentality in Ecuador: neoliberalism, centralization, and the restraining of polycentric authority and community rule-making. Geoforum 64, 281-291.

Brisbois, M.C., Morris, M., de Loë, R., 2019. Augmenting the IAD framework to reveal power in collaborative governance - an illustrative application to resource industry dominated processes. World Dev. 120, 159-168.

Broekman, A., 2013. Reclaiming global citizenship: a perspective from Catalan water justice activists. In: Harris, L.M., Goldin, J.A., Sneddon, C. (Eds.), Contemporary Water Governance in the Global South: Scarcity, Marketization and Participation. Routledge, London, pp. 232-241.

Bukowski, J., 2017. A "new water culture" on the Iberian Peninsula? Evaluating epistemic community impact on water resources management policy. Environment and Planning C: Politics and Space 35 (2), 239-264.

Chatterjee, P., 2004. The Politics of the Governed: Reflections on Popular Politics in Most of the World. Columbia University Press, New York.

Cleaver, F., 2018. Everyday water injustice and the politics of accommodation. In: Boelens, R., Perreault, T., Vos, J. (Eds.), Water Justice. Cambridge University Press, 
Cambridge, pp. 246-258.

Clement, F., 2009. Analysing decentralised natural resource governance: proposition for a "politicised" institutional analysis and development framework. Policy Science 43 (2), 129-156.

Clement, F., Suhardiman, D., Bharati, L., 2017. IWRM discourses, institutional holy grail and water justice in Nepal. Water Alternatives 10 (3), 870-887.

Côte, M. (Ed.), 2005. La ville et le désert: le Bas-Sahara algérien, (Karthala Éditions).

Cox, M., Arnold, G., Villamayor, S., 2010. A review of design principles for communitybased natural resource management. Ecol. Soc. 15 (4), 38.

De Boer, C., Vinke-de Kruijf, J., Özerol, G., Bressers, H., 2016. Collaborative water resource management: what makes up a supportive governance system? Environmental Policy and management 26 (4), 229-241.

De Castro, F., Hogenboom, B., Baud, M. (Eds.), 2016. Environmental Governance in Latin America. Springer, New York.

De Vos, H., Boelens, R., Bustamante, R., 2006. Formal law and local water control in the Andean region: a fiercely contested field. International Journal of Water Resources Development 22 (1), 37-48.

Deleuze, G., Guattari, F., 1987. A Thousand Plateaus: Capitalism and Schizophrenia. University of Minnesota Press, Minneapolis.

Duarte-Abadía, B., Boelens, R., 2016. Disputes over territorial boundaries and diverging valuation languages: the Santurban hydrosocial highlands territory in Colombia. Water Int. 41 (1), 15-36.

Duarte-Abadía, B., Boelens, R., Roa-Avendaño, T., 2015. Hydropower, encroachment and the repatterning of hydrosocial territory. The case of Hidrosogamoso in Colombia. Hum. Organ. 74 (3), 243-254.

Duarte-Abadía, B., Boelens, R., Du Pré, L., 2019. Mobilizing water actors and bodies of knowledge. The multi-scalar movement against the Río Grande Dam in Málaga, Spain. Water 11 (3), 410.

Dupuits, E., Bernal, A., 2015. Scaling-up water community organizations: the role of intercommunities networks in multi-level water governance. Flux 1, 19-31.

Dupuits, É., Pflieger, G., 2017. How do transnational grassroots networks reframe the global norms of water and forests governance? Développement durable et territoires. Économie, géographie, politique, droit, sociologie 8 (1), 1-22.

Dupuits, E., Baud, M., Boelens, R., De Castro, F., Hogenboom, B., 2020. Scaling up but losing out? Water commons' dilemmas between transnational movements and grassroots struggles in Latin America (this special issue). https://doi.org/10.1016/j. ecolecon.2020.106625.

Epstein, G., Bennett, A., Gruby, R., Acton, L., Nenadovic, M., 2014. Studying power with the social-ecological system framework. In: Manfredo, M., Vaske, J., Rechkemmer, A., Duke, E. (Eds.), Understanding Society and Natural Resources. Springer, Dordrecht, pp. 111-135.

Formoso, B., Stock, E., 2016. La société civile Cambodgienne: ruptures, incertitudes et ingérences étrangères. In: Formoso, B. (Ed.), Sociétés civiles d'Asie du Sud-Est continentale: Entre pilotage d'État et initiatives citoyennes, Available online at. https:// books.openedition.org/enseditions/6939, Accessed date: 8 November 2019.

Foucault, M., 1991. (1978). Governmentality. In: Burchell, G., Gordon, C., Miller, P. (Eds.), The Foucault Effect: Studies in Governmentality. University of Chicago Press, Chicago, pp. 87-104.

Fraser, N., 2000. Rethinking recognition. New Left Review(May/June) 107-20.

Fuente-Carrasco, M.E., Barkin, D., Clark-Tapia, R., 2019. Governance from below and environmental justice: community water management from the perspective of social metabolism. Ecol. Econ. 160, 52-61.

Gelles, P.H., 2000. Water and Power in Highland Peru: The Cultural Politics of Irrigation and Development. Rutgers University Press, New Brunswick NJ.

Global Water Forum (2014). Hoogesteger, J. et al. (2014). 'Water security struggles', UNESCO, http://www.globalwaterforum.org.

Gómez-Fuentes, A.C., 2012. Movimiento social por una Nueva Cultura del Agua en España. Espacios Públicos 15 (35), 96-113.

Goodwin, G., 2019. The problem and promise of coproduction: politics, history, and autonomy. World Dev. 122, 501-513.

Gumeta-Gómez, F., Durán, E., Bray, D.B., 2016. Multilevel governance for local management of drinking water in Latin America: case studies from Costa Rica, Honduras and Mexico. Acta Universitaria 26, 3-13.

Hall, R., Edelman, M., Borras Jr., S.M., Scoones, I., White, B., Wolford, W., 2015. Resistance, acquiescence or incorporation? An introduction to land grabbing and political reactions 'from below'. J. Peasant Stud. 42 (3-4), 467-488.

Hamamouche, M.F., Kuper, M., Riaux, J., Leduc, C., 2017. Conjunctive use of surface and ground water resources in a community-managed irrigation system - the case of the Sidi Okba palm grove in the Algerian Sahara. Agric. Water Manag. 193, 116-130.

Hamamouche, M.F., Kuper, M., Amichi, H., Lejars, C., Ghodbani, T., 2018. New reading of Saharan agricultural transformation: continuities of ancient oases and their extensions (Algeria). World Dev. 107, 210-223.

Holley, C., Gunningham, N., Shearing, C., 2011. The New Environmental Governance. Routledge Earthscan, Milton Park.

Hommes, L., Boelens, R., 2017. Urbanizing rural waters: rural-urban water transfers and the reconfiguration of hydrosocial territories in Lima. Polit. Geogr. 57, 71-80.

Hommes, L., Boelens, R., Maat, H., 2016. Contested hydrosocial territories and disputed water governance: struggles and competing claims over the Ilisu dam development in southeastern Turkey. Geoforum 71, 9-20.

Hoogesteger, J., 2016. NGOs and the democratization of Ecuadorian water governance: insights from the multi-stakeholder platform el Foro de los Recursos Hídricos. Volunt. Int. J. Volunt. Nonprofit Org. 27 (1), 166-186.

Hoogesteger, J., Verzijl, A., 2015. Grassroots scalar politics: insights from peasant water struggles in the Ecuadorian and Peruvian Andes. Geoforum 62, 13-23.

Hoogesteger, J., Boelens, R., Baud, M., 2016. Territorial pluralism: water users' multiscalar struggles against state ordering in Ecuador's highlands. Water Int. 41 (1),
91-106.

Horowitz, L.S., 2011. Interpreting industry's impacts: micropolitical ecologies of divergent community responses. Dev. Chang. 42 (6), 1379-1391.

Idda, S., Bonté, B., Mansour, H., Bellal, S.A., Kuper, M., 2017. Monument historique ou système bien vivant? Les foggaras des oasis du Touat (Algérie) et leur réalimentation en eau par pompage. Cahiers Agricultures 26 (5), 1-9.

Ilahiane, H., 2004. Ethnicities, Community Making, and Agrarian Change: The Political Ecology of a Moroccan Oasis. University Press of America.

Isham, J., Kähkönen, S., 2002. Institutional determinants of the impact of communitybased water services: evidence from Sri Lanka and India. Econ. Dev. Cult. Chang. 50 (3), 667-691.

Ivars, B., Venot, J.P., 2019. Entre Politiques Publiques et Matérialité: Associations d'Usagers et Infrastructures d'Irrigation au Cambodge. (Nature Sciences Sociétés).

Johnston, B.J. (Ed.), 2012. Water, Cultural Diversity, and Global Environmental Change: Emerging Trends, Sustainable Futures? UNESCO. Springer, Dordrecht.

Komakech, H., Van der Zaag, P., 2013. Polycentrism and pitfalls: the formation of water users forums in Tanzania. Water Int. 38 (3), 231-249.

Kuper, M., Faysse, N., Hammani, A., Hartani, T., Marlet, S., Hamamouche, M.F., Ameur, F., 2016. Liberation or Anarchy? The Janus Nature of Groundwater Use on North Africa's New Irrigation Frontiers. In Integrated Groundwater Management (pp. 583-615) Springer, Cham.

Kuper, M., Amichi, H., Mayaux, P.L., 2017. Groundwater use in North Africa as a cautionary tale for climate change adaptation. Water Int. 42 (6), 725-740.

Lankford, B., Hepworth, N., 2010. The cathedral and the bazaar: monocentric and polycentric river basin management. Water Alternatives 3 (1), 82-101.

Lansing, J.S., 1987. Balinese "water temples" and the management of irrigation. American Anthropologist New Series 89 (2), 326-341.

Lees, S.H., 1986. Coping with bureaucracy: survival strategies in irrigated agriculture. Am. Anthropol. 88 (3), 610-622.

Li, T.M., 2007. The Will to Improve: Governmentality, Development, and the Practice of Politics. Duke University Press, Durham, NC.

Long, N., 2004. Actors, interfaces and development intervention: meanings, purposes and powers. In: Kontinen, T. (Ed.), Development Intervention. Actor and Activity Perspectives. University of Helsinki, Helsinki, pp. 14-36.

Martínez-Alier, J., 2002. The Environmentalism of the Poor. Edward Elgar, Cheltenham.

McGinnis, M.D., 2011. An introduction to IAD and the language of the Ostrom workshop: a simple guide to a complex framework. Policy Stud. J. 39 (1), 169-184.

McGinnis, M.D., Ostrom, E., 2014. Social-ecological system framework: initial changes and continuing challenges. Ecol. Soc. 19 (2), 30. https://doi.org/10.5751/ES-06387190230.

Meehan, K., 2013. Disciplining de facto development: water theft and hydrosocial order in Tijuana. Environment and Planning D: Society and Space 31, 319-336.

Mekki, I., Jacob, F., Marlet, S., Ghazouani, W., 2013. Management of groundwater resources in relation to oasis sustainability: the case of the Nefzawa region in Tunisia. J. Environ. Manag. 121, 142-151.

Molle, F., 2008. Nirvana concepts, narratives and policy models: insights from the water sector. Water alternatives 1 (1), 131-156.

Molle, F., Mollinga, P., Wester, P., 2009. Hydraulic bureaucracies and the hydraulic mission: flows of water, flows of power. Water alternatives 2 (3), 328-349.

Mosse, D., 2003. The Rule of Water: Statecraft, Ecology and Collective Action in South India. Oxford University Press.

Mostert, E., 2017. Between arguments, interests and expertise: the institutional development of the Dutch water boards, 1953-present. Water History 9 (2), 129-146.

Mutambara, S., Darkoh, M.B., Atlhopheng, J.R., 2016. A comparative review of water management sustainability challenges in smallholder irrigation schemes in Africa and Asia. Agric. Water Manag. 171, 63-72.

Oré, M.T., Rap, E., 2009. Políticas neoliberales de agua en el Perú. Antecedentes y entretelones de la ley de recursos hídricos. Debates en Sociología (34), 32-66.

Oré, M.T., del Castillo, L., Orsel, S., Vos, J., 2009. El agua ante nuevos desafíos. Actores e iniciativas en Ecuador, Perú y Bolivia. Oxfam Internacional e Instituto de Estudios Peruanos, Lima.

Orlove, B., Caton, S., 2010. Water sustainability: anthropological approaches and prospects. Annu. Rev. Anthropol. 39, 401-415.

Ostrom, E., 1990. Governing the Commons. The Evolution of Institutions for Collective Action. Cambridge University Press, Cambridge.

Ostrom, E., 2009. A general framework for analyzing sustainability of social-ecological systems. Science, New Series 325 (5939), 419-422.

Ostrom, E., Cox, M., 2010. Moving beyond panaceas: a multi-tiered diagnostic approach for social-ecological analysis. Environ. Conserv. 37 (4), 451-463.

Perreault, T., 2008. Custom and contradiction: rural water governance and the politics of usos y costumbres in Bolivia's irrigators' movement. Ann. Assoc. Am. Geogr. 98 (4), 834-854.

Pfaffenberger, B., 1988. Fetishised objects and humanised nature: towards an anthropology of technology. Man (N.S.) 23, 236-252.

Poteete, A.R., Janssen, M.A., Ostrom, E. (Eds.), 2010. Working Together. Collective Action, the Commons, and Multiple Methods in Practice. Princeton University Press, Princeton.

Richard Ferroudji, A. (forthcoming). Dynamiques dans la gouvernance locale en Inde: le cas des Tanks dans la region de Pondichery. Revue Gouvernance.

Ricks, J., 2015. Pockets of participation: bureaucratic incentives and participatory irrigation management in Thailand. Water Alternatives 8 (2), 193-214.

Romano, S., 2017. Building capacities for sustainable water governance at the grassroots: "organic empowerment" and its policy implications in Nicaragua. Soc. Nat. Resour. 30 (4), 471-487.

Roth, D., Boelens, R., Zwarteveen, M. (Eds.), 2005. Liquid Relations. Contested Water Rights and Legal Complexity. Rutgers University Press, New Brunswick NJ. 
Roth, D., Boelens, R., Zwarteveen, M., 2015. Property, legal pluralism, and water rights: the critical analysis of water governance and the politics of recognizing "local" rights. Journal of Legal Pluralism and Unofficial Law 47 (3), 456-475.

Sanchis-Ibor, C., Boelens, R., García-Mollá, M., 2017. Collective irrigation reloaded. Reinvention of water management after privatization. Geoforum 87, 38-47.

Schlosberg, D., 2004. Reconceiving environmental justice: global movements and political theories. Environmental Politics 13 (3), 517-540.

Schulz, C., Martin-Ortega, J., Glenk, K., Ioris, A., 2017. The value base of water governance: a multi-disciplinary perspective. Ecol. Econ. 131, 241-249.

Sillitoe, P. (Ed.), 2017. Indigenous Knowledge: Enhancing its Contribution to Natural Resources Management. CABI.

Singto, C., Fleskens, L., Vos, J., 2018. Institutionalizing participation in water resource development: bottom-up and top-down practices in southern Thailand. Water 10 (6), 781.

SOPPECOM, 2010. Study of Social Movement on Water in India. Pune. https://www. soppecom.org/pdf/report-study-of-social-movements-on-water-in-India.pdf.

Suhardiman, D., Giordano, M., Rap, E., Wegerich, K., 2014. Bureaucratic reform in irrigation: a review of four case studies. Water Alternatives 7 (3), 442-463.

Suhardiman, D., Nicol, A., Mapedza, E. (Eds.), 2017. Water Governance and Collective Action. Multi-Scale Challenges. Routledge, London and New York.

Swyngedouw, E., 2007. Technonatural revolutions: the scalar politics of Franco's hydrosocial dream for Spain, 1939-1975. Trans. Inst. Br. Geogr. 32 (1), 9-28.

Swyngedouw, E., Boelens, R., 2018. ‘... and not a single injustice remains' - Hydro-territorial colonization and techno-political transformation in Spain. In: Boelens, R. Perreault, T., Vos, J. (Eds.), Water justice. Cambridge University Press, Cambridge, pp. 115-133.

Van den Berge, J., Boelens, R., Vos, J., 2018. Uniting diversity to build Europe's water movement Right2Water. In: Boelens, R., Perreault, T., Vos, J. (Eds.), Water Justice.
Cambridge University Press, Cambridge, pp. 226-245

Venot, J.P., Clement, F., 2013. Justice in development? An analysis of water interventions in the rural south. Nat. Res. Forum 37, 19-30.

Villamayor-Tomas, S., 2018. Polycentricity in the water-energy nexus: a comparison of polycentric governance traits and implications for adaptive capacity of water user associations in Spain. Environ. Policy Gov. 28 (4), 252-268.

Villamayor-Tomas, S., García-López, G., 2018. Social movements as key actors in governing the commons: evidence from community-based resource management cases across the world. Glob. Environ. Chang. 53, 114-126.

Vos, J., 2005. Understanding water delivery performance in a large-scale irrigation system in Peru. Irrigation and Drainage: The journal of the International Commission on Irrigation and Drainage 54 (1), 67-78.

Vos, J., Boelens, R., 2014. Sustainability standards and the water question. Dev. Chang. 45 (2), 205-230.

Vos, J., Vincent, L., 2011. Volumetric water control in a large-scale open canal irrigation system with many smallholders: the case of Chancay-Lambayeque in Peru. Agric. Water Manag. 98 (4), 705-714.

Warner, J.F., 2006. More sustainable participation? Multi-stakeholder platforms for integrated catchment management. International Journal of Water Resources Development 22 (1), 15-36.

Whaley, L., 2018. The critical institutional analysis and development (CIAD) framework. Int. J. Commons 12 (2), 137-161.

Woodhouse, P., Veldwisch, G.J., Venot, J.P., Brockington, D., Komakech, H., Manjichi, Â, 2016. African farmer-led irrigation development: re-framing agricultural policy and investment? J. Peasant Stud. 67, 1-21.

Zwarteveen, M., Boelens, R., 2014. Defining, researching and struggling for water justice: some conceptual building blocks for research and action. Water Int. 39 (2), 143-158. 